\title{
Real World Research - Using Collaboration between Researcher and Practitioner to Maximize Research Outcomes
}

\author{
Dr. Janet Murray \\ Director, Murray Consulting \& Training, \\ PO Box 329, Ocean Grove, Victoria 3226, \\ Australia \\ murray@gsat.edu.au \\ Barbara Bugg \\ Head of Library and Curriculum Resources \\ Bayside Secondary College \\ Newport, Victoria 3015. \\ Australia. \\ bugg.barbara.r@edumail.vic.gov.au
}

\begin{abstract}
This paper focuses on the relationship between researcher and practitioner, and discusses the mutual benefits to each. Janet Murray's doctoral research used case study as a primary research technique. One of the case study schools was Essendon Keilor College in Victoria, where Barbara Bugg was then Head of Curriculum Resources. Both authors realised the benefits of working together and felt that it was important to communicate to others how the process worked. The paper will discuss the factors that contributed to the development of an excellent working relationship between the research team and the school library staff. Methods of effective communication, provision of feedback and dissemination of research results throughout the school are also described.
\end{abstract}

\section{Introduction}

Janet Murray's doctoral research used case study as a primary research technique. Methodological triangulation was achieved by using multiple case studies and document analysis alongside a longitudinal survey approach. Fourteen primary and secondary schools in two Australian states, Victoria and NSW, participated as case studies in the project that evaluated school library service for students with special needs in mainstream schools. One of the case study schools was Essendon Keilor College in Victoria, where Barbara Bugg was then Head of Curriculum Resources. Both authors realised the benefits of working together and felt that it was important to communicate to others how the process worked. The results of the research have been disseminated previously (Murray 2000a, 2000b, 2001). This article focuses on the relationship between researcher and practitioner.

\section{The Research Approach}

This relationship was the focus of the research design. The key approach lay within the interpretivist paradigm, informed by the reflective research approach advocated by Fook (1996) and Adler (1993) and the emancipatory research approach being applied in the disability field (Abberley 1987, Oliver 1996). Adler (1993) has identified four elements in this type of reflective research practice : awareness and responsibility to the professional 
community; attention to the contexts of practice; searching for patterns and anomalies seeking meanings from experience; and the ongoing spiral nature of research. Adler describes the way in which a researcher working in an area within which they have extensive practical experience, will use this experience to maintain a critical awareness of what is happening in the research arena, and subsequently retrospectively reflect to make sense of what happened. Oliver (1996) explains how past treatment of people with disabilities as research subjects has alienated them from research. Even with an interpretivist approach, there is still a group of "expert" researchers and a group of research subjects, and this can be just as alienating as positivist research. Methodology must also change to accommodate participation and reciprocity. Emancipatory research has a different view of knowledge and aims to ...illuminate the lived experiences of progressive social groups; it must also be illuminated by their struggles. Theory adequate to the task of changing the world must be open-ended, non-dogmatic, informing, and grounded in the circumstances of everyday life.

(Lather 1986, p.262.)

Emancipatory research enables people to change by encouraging self-reflection and a better understanding of their particular situations.

The study was also informed by the work of Carr \& Kemmis (1986) in attempting to develop a research approach to suit the educational setting. Although their preferred approach is action research, which was not undertaken in this study, their deliberations concerning the relationship of the positivist and interpretive approaches to educational research have relevance to a decision to use a methodology that involved both. They say

...it is clear that what is required is a view of educational research which is both 'interpretive' and scientific. 'Interpretive' in the sense that it generates theories that can be... utilised by practitioners in terms of their own concepts and theories; 'scientific' in the sense that these theories provide a coherent challenge to the beliefs and assumptions incorporated in the theories of educational practice that practitioners actually employ.

(Carr \& Kemmis 1986, p.118)

The close relationship between research and practice in the field of librarianship favoured the reflective research approach that could be employed in the case study technique. The researcher's experience as a school librarian and a library educator enabled her to interpret her observations and data collection in schools with expertise. She was regarded by some school librarians in case study schools as an expert in the field. Therefore they might ask for advice, or initiate an informed discussion as to how they might approach the management of services to students with special needs. In many instances school librarians would comment that the very presence of the researcher in the school was an awareness raising activity in itself. Thus once the researcher became involved in the case study school, she was bordering on being a participant observer, and was certainly following the interpretivist and at times the emancipatory approach in her research.

The researcher also focussed on the influence of research findings on practice, based on the ideas of Argyris and Schon (1974). In case study schools, the investigation aimed to identify whether the espoused theory of school librarians and special educators, and others, in relation to phenomena related to the study were in fact the same as or different to their theory-in-use. Thus observation by the researcher and accounts of actions by other people would inform this line of enquiry. There was a conscious effort to provide feedback to schools, not only in asking for comments on interview transcripts, but on other research 
outputs such as journal articles and conference papers. These were sent to school librarians in case study schools and to bodies such as the Catholic Education Offices, with an encouragement to disseminate these to school staff who had participated in the study and to other interested persons.

\section{Future Research}

These types of research approaches could be used more widely in school library research. At a time when more research needs to be done in schools, school librarians may be encouraged to participate in research activities. The interrelationship between research and practice is vital - these two cannot be separated, and the need for practitioners to be involved in research and for research to be done with reference to the "real" world is paramount. Practitioners can gain assistance with solving workplace issues and problems; receive assistance with developing new skills and knowledge; and becoming aware of new ideas or emerging research and using these to develop and change service provision and improve management approaches. For researchers, initiating research projects which have a practical as well as a theoretical approach ensures that work is credible, meets accountability and produces outcomes which benefit the profession as a whole.

There were several reasons why the involvement of Essendon Keilor College in the Monash University project worked well. Firstly Barbara Bugg and Janet Murray had worked together as lecturers in Information Management at the University of Melbourne, so they had an excellent previous working relationship to build on; secondly the Principal of the school supported the project and the Special Education Department were keen from the start, due to Barbara's "selling" of the project; thirdly, the research design took into account Janet's skills and expertise. She had been a practicing school librarian and had also held positions involving liaison with school libraries. As a lecturer in Information Management, she had taught in and been involved in course design for various courses offering qualifications in school librarianship, as well as conducting prior research in the area. Thus she was able to identify with the management of a school library and the role of the school librarian.

Obviously good working relationships such as this can be the foundation for collaboration in research, but there are other situations that foster collaborative programs. Most of these are founded in the professional networking that takes place between schools of librarianship/information management and relevant professional associations. Both library educators and researchers, and practitioners have a professional interest in developing good channels of communication in a variety of ways. These include: participation in conferences; attendance at professional meetings; the use of practitioners as guest lecturers; the involvement of library educators/researchers as consultants; the development and continued support of alumni associations; work experience placements of librarianship/information management students. A study by Bridgland \& Hazell (1992) investigated how well these avenues were used in both Australia and Canada. It was found that all these avenues were well used but in different ways, some positive and some negative. One example was the use of practitioners as guest lecturers in librarianship/information management courses. In the best practice scenarios this came about because schools wanted to involve practitioners as much as possible in their courses, and facilitate communication between practitioners and students. In some schools, use of practitioners in this way might "....indicate that the school is understaffed or has an inappropriate mix of staff expertise" (p.23).

However the opportunity for collaboration arises, there are benefits for all involved. 


\section{Benefits for the Practitioner}

A research project can be a very valuable link to the academic world and was useful in the school context as well. In the research project that is described in this paper, the practitioner was initially interested because she recognised that services for students with disabilities was becoming an important area, and she welcomed the opportunity for some evaluation to be conducted.

Essendon Keilor College is a multi campus school. There were two disabled students at the Senior Campus, one of whom was confined to a wheelchair. There was also another student who used wheelchair at a Junior Campus and eventually this student would come to the Senior Campus. Several other students across the school had learning disabilities or intellectual disabilities, and there was also a Support Unit for autistic students at one of the junior campuses.

A new library at the Senior Campus had just been constructed when the approach was made to the school to become involved in the research project. In fact the collaboration provided the school with a consultant with significant experience in library service for people with disabilities. She was able to advise on the physical set up of the new library, and on various policy issues. The evaluation of course also provided valuable data on how well the library was catering for a range of students with various disabilities and learning difficulties. The researcher interviewed students, special education teachers and library staff at all three school campuses. This was something that the school library manager would not have been able to fund or find the time to carry out herself.

There was also some kudos for the school in having the library as a research base from the school's point of view. The school was involved in another project at the time with the Philosophy Department of the University of Melbourne, so a project with another university was seen to be beneficial. It gave the Library credibility in the school. The library was also involved with other research on the impact on school collections and the Victorian Certificate of Education, so this type of involvement was beginning to be part of the scene.

The exposure to researchers was good for the library as well. Observing them working in the library sparked other ideas. Their interviews often raised issues that library staff had not thought about and stirred them into action. It also made them aware of the issues that were being investigated; the disabled students had been considered before but the process was evaluated and that motivated library staff to question whether or not enough had been done.

As it turned out, the research about services for disabled students was extremely valuable in a very practical way when the Administration tried to move the shelving for a launch that was held in the library. The library staff was not in favour of moving this shelving, as you might expect, because it would be a domino effect. If it was seen to be done once, it could be done again and the library space could be invaded more seriously. The one thing that saved all that work, was the fact that there had been a research project from the 'University' that said that the shelves were well positioned. This may seem like a small reason for involving yourself in a research project, but the library staff were very grateful. 


\section{Benefits for the Researcher}

Finding schools that are willing to participate in research is always a daunting task for a researcher. Many schools fear that the research will take up too much time, it will be intrusive and there will not be any benefits for the school. When the research project described here first started, many hours were spent on the phone, talking to school librarians from schools identified through personal and professional networks. Schools were needed that fulfilled certain criteria - to have a number of disabled students enrolled, to have qualified special education teachers and a library managed by a qualified librarian - and also a school librarian who was willing to participate in the research and a principal who supported the idea! When Essendon Keilor College actually offered to participate in the research, this was a great bonus.

Obviously the previous working relationship between the researcher and practitioner had distinct advantages - there was established trust, they knew one another's methods of approaching problems and challenges, and knew they could work well together. The researcher established excellent relationships with other school librarians at other schools who participated in the study, which was one of the most valuable outputs, but at Essendon Keilor College time did not need to be spent in establishing the relationship with the main participant, although of course it was with other school librarians at the college. Barbara, the practitioner was aware of the significance of the research through her previous experience of dealing with students with disabilities, so she was able to involve the interest and support of the Principal and the Special Education Department on behalf of the researcher, which was a great advantage.

At the time the research commenced, in the Department of Library and Information Studies at the University of Melbourne, one subject taught in the post-graduate course was Professional Practice and Research. In this subject, students with good grades were offered the option of assisting a lecturer with a research project as one part of their assessment. Janet Murray had three such students working with her on the research project. These students conducted some of the interviewing at Essendon Keilor College. All were experienced teachers, so the school environment was not new to them, but the opportunity to have professional contact with school librarians and observe library practice was an obvious benefit.

The study as a whole showed that research could have a direct effect on practice. For example, many survey respondents commented that the questionnaire had made them think about what sorts of services they should be providing for disabled students, and that this was helpful. Changes in case study schools were also noticed, varying from redesigning the layout of the library through to the solving of management problems. The researcher sometimes found herself in the role of "consultant" but this was acceptable due to the interpretivist approach to the research. School librarians and special education teachers often asked for advice and the researcher was able to provide this from her own experience but also from information collected from other case study schools, so it was a dynamic process.

\section{Feedback from Research}

We have already mentioned how important it is for researchers to liaise with practitioners when conducting any research. When practitioners are very closely involved in research, as in the current example, researchers must give feedback to schools. In this case, this was done by sending copies of interview transcripts for vetting, and providing copies of 
any publications arising from the research. Barbara felt she was informed on how the research was going, and that the library staff was helping to drive the research along.

It is also important to disseminate the results of research to the wider audience of practicing teacher-librarians and school librarians. One of the issues around school library research is that much of the research that is done is not reported. Many research projects completed in the course of writing a master's thesis in the area of school librarianship are never reported in the literature. This is a great loss for both practitioners and researchers. Ken Haycock $(1992,1997)$ has done considerable work to gather together unpublished research of this type in Canada. Library educators and researchers in other countries should consider following this example, and also seek other strategies to ensure the reporting of research.

Although many school librarians have undertaken action research in their own schools, there are great benefits in doing research in other schools rather than their own. This makes it easier to look at the situation critically. Most school librarians participating in the study described found it helpful to have the researcher to draw on as a "critical friend".

\section{Conclusion}

The research process is a two way street. The researcher certainly provides the school with benefits. The benefits are not always immediate but in the fullness of time the research can be a valuable tool for the school librarian, the library and the school. The process is not that difficult or time-consuming when the positive outcomes are considered. The benefits to you are not always apparent at the time but will bear fruit eventually, and often in unexpected ways. The resulting research will assist other practitioners and other researchers and contribute to the continued improvement of school library services.

The authors believe that the results of research are not always effectively disseminated to the wider audience of practicing teacher-librarians and school librarians. This is a great loss for both practitioners and researchers, and strategies to improve this situation need to be developed.

\section{References}

Abberley, P. (1987). The concept of oppression and the development of a social theory of disability. Disability, Handicap and Society, 2 (1) 5-20.

Adler, S. (1993). Teacher education: research as reflective practice. Teaching and Teacher Education, 9 (2) 159-67.

Argyris, C. \& Schon, D. A. (1974). Theory in Practice : Increasing Professional Effectiveness. San Francisco: Jossey Bass.

Bridgland, A. \& Hazell, A. (1992). Common ground: Communication between Schools of Library Studies and Practitioners. in Libraries: The heart of the matter. Proceedings of the Australian Library and Information Association $2^{\text {nd }}$ Biennial Conference. Canberra: Australian Library and Information Association. pp. 23-27. 
Carr, W. \& Kemmis, S. (1986). Becoming Critical. Rev. Ed. Geelong : Deakin University Press.

Fook, J. (1996). The Reflective Researcher: Social Workers' Theories of Practice Research. St Leonards, N.S.W. : Allen \& Unwin.

Haycock, K. (1992). What Works: Research about Teaching and Learning through the School's Library Resource Centre. Seattle, Washington: Rocklands Press.

Haycock, K. (1997). Reinventing School Libraries: Alternatives, Models and Options for the Future. Forging Forward: National Symposium on Information, Literacy and the School Library in Canada. November $21^{\text {st }}$. http://gateway2.uvic.ca/symposium/haycock.htr

Lather, P. (1986). Research as praxis. Harvard Educational Review, 56 257-273.

Murray, J.R. (2000a). How school librarians can contribute to the personal growth of students with disabilities. Orana: Journal of School and Children's Librarianship, 36 (2) July, 5-13.

Murray, J.R. (2001). Teaching information skills to students with disabilities: What works? School Libraries Worldwide, 7 (2) July, 1-16.

Murray, J.R. (2000b). The training needs of school library staff for service delivery to disabled students. School Libraries Worldwide, 6 (2) July, 21-29.

Oliver, M. (1996). Understanding Disability : From Theory to Practice. Basingstoke : MacMillan. Note This paper expands on a theme briefly explored in a short article in the Australian journal Access to be
published in 2002 . 